\title{
Singapore's 2030 Zero Waste Masterplan (ZMP): Is it Achievable?
}

\author{
Li Gin Siow ${ }^{1}$ and Charles CC Lee ${ }^{2}$ \\ ${ }^{1}$ University of Newcastle (Australia) Singapore alumni affiliation \\ siowligin@yahoo.com.sg \\ ${ }^{2}$ University of Newcastle (Australia) Singapore \\ 6 Temasek Blvd, Suntec Tower 4, \\ Singapore 038986 \\ charles.cc.lee@newcastle.edu.au
}

\section{Extended Abstract}

In 2019, the Ministry of Environment set a bold direction to move Singapore to a zero-waste nation. The 2030 Zero Waste Masterplan (ZWM) [1] strives to achieve a sustainable, resource-efficient and climate-resilient Singapore. Ambitious targets were set including: (i) extend the landfill's (Semakau) lifespan beyond 2035; (ii) reduce the amount of waste sent to the landfill per capita per day by $30 \%$ by 2030 ; (iii) by 2030 , achieve a $70 \%$ overall recycling rate $(81 \%$ nondomestic and $30 \%$ domestic).

The focus of this paper is to review the key elements of the 2030 ZWM [1,2] and focus on the major challenges of increasing the current domestic recycling rate of only $<10 \%$ to $30 \%$ by 2030 . ZWM aims to adopt and change the nation's sustainability by using the Circular economy approach - Make, Use and Recycle. It also includes the implementation of Extended Producer Responsibility (EPR) by 2021, starting from electronic wastes to the feasibility of packaging wastes. There is another initiative by ZWM to close the Waste loop for plastic materials to be sustainable by making it to be more reusable, easier to recycle, and to extract value from waste plastics.

While the construction waste [3] is efficiently recycled (95\%), a major source of domestic waste, food and plastic wastes are only $8 \%$ and $4 \%$ recycled, respectively. This is rather unimpressive for a developed economy such as Singapore. We believe the challenges related to this poor recycling rate are:

(i) Due to the convenience of throwing household rubbish into the residential chutes which are then efficiently transported to be incinerated, there is a lack of public awareness on the environmental footprint of burning residential wastes.

(ii) Although plastic waste can be sorted and recycled, there is a lack of awareness of the harm to human health and ecology from plastic usage, and no plastic recycling facility exist in Singapore.

(iii) Tons of food waste particularly from the hawker centres, restaurants, and hotels are thrown away to be incinerated!

In order to achieve the ZWM targets by 2030 (only 10 years away) for domestic wastes, we believe the public involvement would need to be started from the "ground-up". This would encompass multi-stakeholder initiatives that goes beyond government sponsored programs. Multi-stakeholder participation could include involvement of non-governmental organisations (NGO), public citizens from the local heartlands, schools (all levels), tertiary institutions (polytechnics and universities) and government. For too long, the public is led by government resource recycling programs, which is clearly not sustainable.

Some multi-stakeholder initiatives [4] that are sustainable could include: (a) educational programs conducted by NGOs and youths on recycling wastes at the school level. Programs would need to focus more on moving away from incineration to understand the value of waste recovery, and the serious impacts of waste on both human health and ecological damage; (b) waste collection to be stepped up at community centres that is headed by public citizens; (c) increased dialogue between citizens, NGOs and government on innovative ways to recycle wastes via virtual networks (such as Zoom, LinkedIn or Facebook); (d) transfer of research outcomes on waste recycling from the tertiary institutions 
to private companies to spinoff new technologies; and (e) increased funding from the government for entrepreneur startups in the area of waste recycling.

On food-related wastes, Singapore generates 763,000 tonnes of food waste a year. The major challenges are - the mismatch in supplies and demand and inefficient inventory management; not fully utilising ingredients when cooking; throwing away blemished or imperfect food; and improper storage of raw food. Some hotels and hawker centres using government incentives are currently applying Thermophilic Digestor technology (e.g. BioMax) to recycle food wastes, which converts the wastes into pathogen-free organic fertilisers to be used for landscaping [5]. This would need to be scaled up rapidly to impact at least 50-60\% of the hotels and hawker centres in order to achieve double digit recycling of food wastes. In affluent Singapore, a massive behaviour transformation in the public mindset on food waste would be urgently required. How do we achieve this? Some aggressive initiatives could embrace using internet technology (e.g. apps) [6] to match excess food in restaurants and supermarkets to be used by needy families (e.g. Treasure, Olio, Makan Rescue). Additionally, households should be taught composting techniques on how to convert food scraps into compost for use as fertilizers [7,8].

On plastic-related wastes, education is key to influencing the public to use less plastic and recycle plastic wastes. As Singapore is a small country, even if we eliminate plastic use and / or reduce plastic waste, the impact on the regional environment is insignificant. However, Singapore's influence on the ASEAN and Asia-Pacific region is significant. A first world country that is serious about reducing its plastic footprint would certainly go a long way to impact its neighbouring countries who are choking the surrounding pristine seas with plastic wastes.

\section{References}

[1] Ministry of the Environment and Water Resources. National Environment Agency. Zero Waste Masterplan Singapore. [Published in Year 2018]. Available from: www.towardszerowaste.sg

[2] Towardszerowaste.gov.sg. 2020 [cited 5 August 2020]. Available from: https://www.towardszerowaste.gov.sg/zerowaste-masterplan/

[3] Land Transport Authority, Singapore. Construction Waste Management at LTA Sites. [Published in October 2009].

[4] Beisheim, M. and Simon, N., 2016. Multi-Stakeholder Partnerships for Implementing the 2030 Agenda: Improving Accountability and Transparency. Analytical Paper for the 2016 ECOSOC Partnership Forum. SSRN Electronic Journal.

[5] Singapore Hotel Association. National Environment Agency. 3R Guidebook for Hotels. [Published in January 2019]. Available from: https://www.pub.gov.sg/sites/assets/PressReleaseDocuments/Annex Factsheet-on-Food-WasteManagement-in Singapore-Website.pdf

[6] Yeap, S., 2020. These Mobile Apps Combat Food Wastage In Singapore. [online] Lifestyle Asia Singapore. Available at: <https://www.lifestyleasia.com/sg/food-drink/mobile-apps-combating-food-wastage-singapore/> [Accessed 6 August 2020].

[7] Mark, R. and Britt, F., 2009. Food Waste Composting: Institutional And Industrial Applications. The University of Georgia

[8] Chee, G. and Yusoff, S., 2015. Life Cycle Inventory of Institutional Medium-scaled Co-composting of Food Waste and Yard Waste in Tropical Country. Sains Malaysiana, 44(4), pp.517-527. 